\title{
Assessment of damage to the central nervous system by determination of S-100 protein in the cerebrospinal fluid
}

\author{
CJM SINDIC, $\ddagger$ MP CHALON $†$ CL CAMBIASO,${ }^{*}$ EC LATERRE $\dagger \dagger$ PL MASSON* \\ From the *Unit of Experimental Medicine, International Institute of Cellular and Molecular Pathology, and \\ †Laboratoire de Neurochimie, Université Catholique de Louvain, Brussels, Belgium
}

SUMMARY S-100 protein was determined by Particle Counting ImmunoAssay in the CSF of patients with various neurological disorders. With a limit of sensitivity of $2.5 \mu \mathrm{g} / \mathrm{l}$ this brain-specific protein was detected only in samples from patients with acute damage of the central nervous system, particularly in compression of the spinal cord by tumour, ischaemic disorders, subarachnoïd bleeding and haematoma, and viral or suspected viral infections. Our results support the assumption that $\mathrm{S}-100$ is a reliable index of central nervous system damage and that changes in its concentration could have a prognostic value.

$\mathrm{S}-100$ protein is an acidic protein of molecular weight $21,000^{1}$ found essentially in the nervous system of vertebrates. " This protein is called "S-100" because of its solubility in $100 \%$ saturated ammonium sulphate at neutral $\mathrm{pH}$. A characteristic of $\mathrm{S}-100$ is its structural changes caused by calcium ions. ${ }^{3} \mathrm{~S}-100$ is, in fact, a family of proteins ${ }^{4-8}$ shown by complement fixation and cross-immunoelectrophoresis ${ }^{9}$ to be antigenically different. Two main types have been described $.^{67} \mathrm{~S}-100$ a containing two different subunits ( $\alpha$ and $\beta$ subunits) and S100b, two identical subunits ( $\beta$ subunits).

$\mathrm{S}-100$, the function of which is still unknown, is located mainly in the astrocytes ${ }^{10-19}$ but has also been detected in the interstitial cells of the pineal gland, ${ }^{16}$ in satellite cells of the adrenal medulla and the superior cervical ganglion,,$^{20}$ in the pituicytes and the stellate cells of the pituitary gland, ${ }^{2122}$ in melanocytes, ${ }^{23}$ in cells with morphological features of Langerhans cells in the skin, ${ }^{23}$ in malignant melanomas, ${ }^{2425}$ and in acoustic neurinomas, sometimes in large amounts. ${ }^{26}$

The purpose of the present work was to test the

$\ddagger$ Aspirant at the "Fonds National de la Recherche Scientifique", Brussels, Belgium

Address for reprint requests: Dr CJM Sindic, Unit of Experimental Medicine. Avenue Hippocrate 75, ICP 7430, B-1200 Brussels, Belgium.

Received 5 April 1982 and in revised form 26 June 1982. Accepted 10 July 1982 hypothesis that $\mathrm{S}-100$ is released into the cerebrospinal fluid (CSF) by lesions of the central nervous system (CNS) and that its determination can be useful in assessing the extent of brain damage.

\section{Materials and methods}

Patients The CSF was collected for routine analysis from patients of the Department of Neurology, Cliniques SaintLuc, Brussels by spinal puncture. After centrifugation 0.5 to $2 \mathrm{ml}$ aliquots were kept frozen at $-20^{\circ} \mathrm{C}$. The clinical records of these patients were reviewed retrospectively. Patients with unconfirmed diagnoses were excluded from the study. The control group comprised non-neurological patients suffering from minor neurosis but devoid of clinical signs of neurological disorders. Electroencephalography and computed tomography were normal, as well as CSF analyses comprising total protein content (below or equal to $0.4 \mathrm{~g} / \mathrm{l}$ ), cell count (below or equal to $5 / \mathrm{cmm}$ ) and agar gel electrophoresis.

Purification of S-100 S-100 was isolated from bovine brains obtained at the abbatoir immediately after death of the animal and purified as described by Steward. ${ }^{+}$The last step was an elution from a DEAE-cellulose column $(1.5 \times$ $15 \mathrm{~cm}$ ) by a linear gradient of $250 \mathrm{ml}$ of potassium phosphate buffer, $(0 \cdot 01 \mathrm{M}, \mathrm{pH} 7 \cdot 2$, containing $1 \mathrm{mM}$ EDTA, and 1 $\mathrm{mM} 2$-mercaptoethanol) in $0.05 \mathrm{M} \mathrm{NaCl}$, and $250 \mathrm{ml}$ in 0.6 $\mathrm{M} \mathrm{NaCl}$. The main fraction was collected, extensively dialysed and stored lyophilised at $-20^{\circ} \mathrm{C}$.

Acrylamide gel electrophoresis A single band was visible in slab gel containing sodium dodecyl sulphate and in disc-gel acrylamide electrophoresis at $\mathrm{pH} 8 \cdot 1$ (fig 1). Addition of 


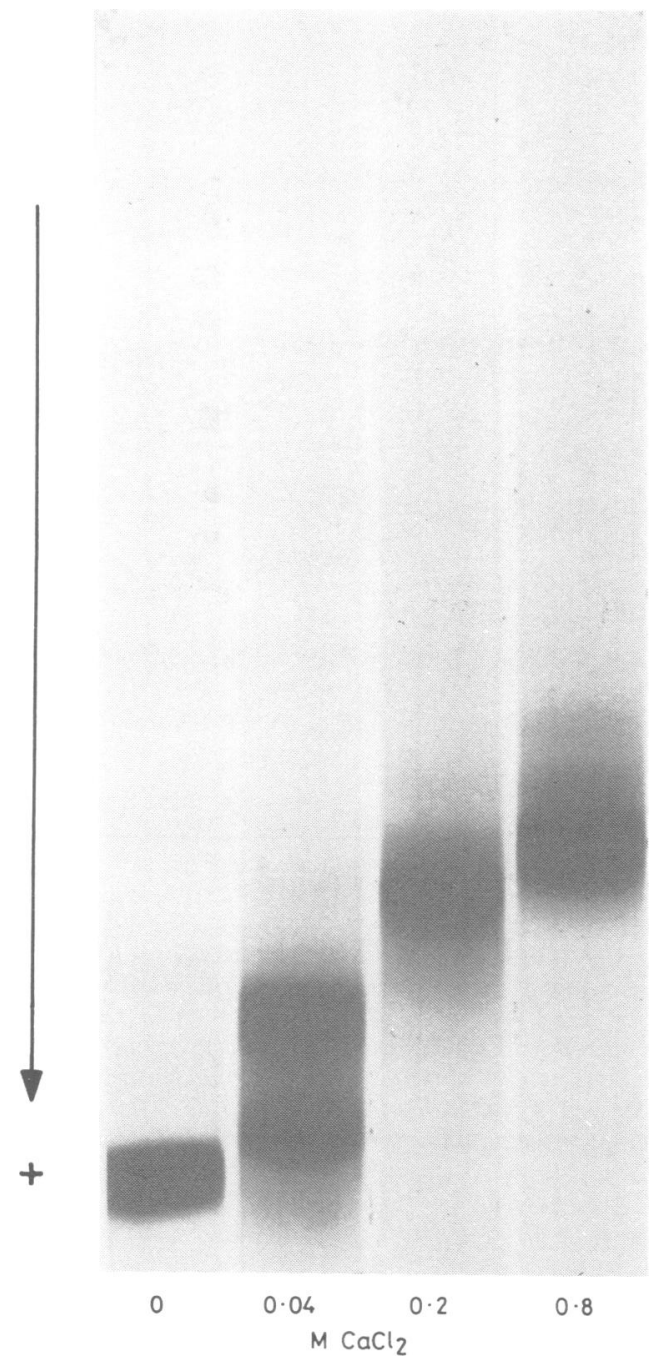

Fig 1 Disc-gel electrophoresis of $25 \mu \mathrm{g}$ of S-100 in $7.5 \%$ polyacrylamide gels in tris-glycine buffer, $p H 8 \cdot 1$. From left to right: in absence of $\mathrm{CaCl}_{2}$ and in presence of $0 \cdot 04,0 \cdot 2$ and $0.8 \mathrm{M} \mathrm{CaCl}_{2}$. Electrophoresis was run until the marker dye (bromophenol blue) migrated $7.5 \mathrm{~cm}$.

$\mathrm{Ca}^{++}$to samples, gel and buffers slowed down the mobility of S-100 in disc-gel electrophoresis (fig 1) because of the structural changes ${ }^{3}$ of the protein.

Anti-S-100 antiserum Four rabbits were injected twice a month with a methylated bovine serum albumin S-100 conjugate. ${ }^{27}$ Bovine serum albumin (bSA) was from Calbiochem, la Jolla, California. After three injections, blood $(50 \mathrm{ml})$ was collected one week after each injection. The antiserum was absorbed on bSA and on a pool of sera of 1,000 blood donors. The absorbing antigens were coupled to CNBr-activated Sepharose 4B (Pharmacia. Uppsala, Sweden). ${ }^{2 \times}$ After precipitation by half-saturated ammonium sulphate the $\operatorname{IgG}$ of the antiserum was isolated by DEAE-cellulose chromatography in $0.1 \mathrm{M}$ tris (hydroxymethyl) methylamine- $\mathrm{HCl}, \mathrm{pH} 8 \cdot 5$, and then digested by pepsin (Sigma Chemical Co. St-Louis, Mo.) as previously described. ${ }^{24}$ The $F\left(a h^{\prime}\right)$, fragments were purified on an Ultrogel AcA 4-4 column $(2.5 \times 100 \mathrm{~cm})(\mathrm{LKB}$, Bromma, Sweden) in $1 \mathrm{M} \mathrm{NaCl}$ buffered by (0.01 $\mathrm{M}$ phosphate buffer. $\mathrm{pH} 7 \cdot 2$. Single precipitin lines were obtained in agarose gel double immunodiffusion with bovine and human brain aqueous extracts; both lines fused completely. No reaction occurred with liver extracts. This antiserum was used in an immunofluorescence study of primary cultures of brain cells from newborn rats. ${ }^{30}$ Specific fluorescence was seen in the cytoplasm and nuclei of astrocytes. Cultures of fibroblasts from meninges were not stained.

Immunoassay of S-100 S-100 levels in the CSF were determined by Particle Counting ImmunoAssay (PACIA) (Technicon International Division, Geneva, Switzerland). This now fully automated technique is based on latex agglutination. Particles coated with antibodies were agglutinated by the antigen to be determined." The use of $\mathrm{F}(\mathrm{ab})^{\prime}$ : fragments rather than whole antibody molecules avoided non-specific agglutination or inhibition of agglutination by proteins interacting with the $\mathrm{Fc}$ region of IgG. ${ }^{32}$ Residual interferences by protein-protein interaction were avoided by the use of a detergent (Tween 20 . Technicon) in a final concentration of $3.3 \mathrm{ml} / \mathrm{l}$. Agglutination was measured by counting the residual unagglutinated particles in an optical cell counter whose electronics have been modified to ignore aggregates. The anti-S-100 $\mathrm{F}\left(\mathrm{a} \mathrm{b}^{\prime}\right)$, fragments were coupled to carboxylated polystyrene particles of $0 \cdot 8 \mu$ diameter $(100 \mathrm{~g} / \mathrm{l}$; Estapor $\mathrm{K}$ 150, batch No 314, Rhône-Poulenc, Courbevoie, France) as previously described. ${ }^{33}$ To $50 \mu \mathrm{l}(100 \mathrm{~g} / \mathrm{l})$ carbodiimideactivated latex was added $300 \mu \mathrm{g} F\left(a b^{\prime}\right)$. Such a preparation which was sufficient for 300 assays was stored at $-20^{\circ} \mathrm{C}$ in small aliquots. The assays were calibrated with purified S-100, serially diluted in $0 \cdot 1 \mathrm{M}$ glycine buffer, $\mathrm{pH}$ $9 \cdot 2$, containing $9 \mathrm{~g} / \mathrm{l}$ of $\mathrm{NaCl}$ (GBS), $10 \mathrm{~g} / \mathrm{l} \mathrm{bSA}$ and made $5 \mathrm{mM}$ in $\mathrm{CaCl}_{2}$. Into the reaction tube were injected sequentially and automatically $30 \mu \mathrm{l}$ each of the sample, of the GBS containing $5 \mathrm{mM} \mathrm{CaCl}_{2}, 60 \mathrm{~g} / \mathrm{l}$ polyethylene glycol and $10 \mathrm{ml} / \mathrm{l}$ Tween 20 , and of the $F\left(a b^{\prime}\right)$ :-coated particles 200 times diluted in GBS containing $2.5 \mathrm{ml} / \mathrm{l}$ Ficoll (Pharmacia). Incubation time was 35 minutes.

\section{Results and Discussion}

\section{THE S-100 IMMUNOASSAY}

A plot of peak heights or concentration of free particles vs log of S-100 concentration formed a decreasing sigmoid curve from $2 \cdot 5$ to $250 \mu \mathrm{g} / \mathrm{l}$ (fig 2 ). For greater accuracy samples containing more than 50 $\mu \mathrm{g} / \mathrm{l}$ were serially diluted. The most important factor which affected the immunoassay was the presence or absence of $\mathrm{Ca}^{++}$(fig 3), as already observed in immunoradiometric assay ${ }^{34}$ but not by electroimmunodiffusion or by microcomplement fixation 


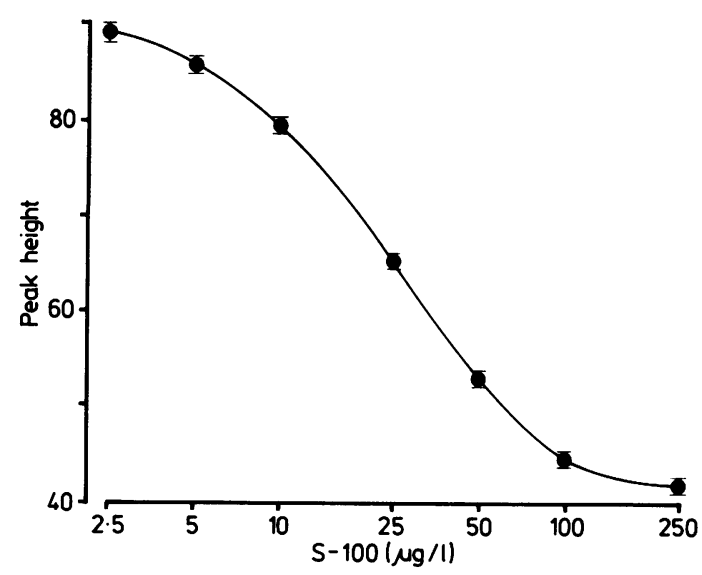

Fig 2 Calibration curve for the assay of S-100 by PACIA in the presence of $5 \mathrm{mM} \mathrm{CaCl}$. The peak heights are directly proportional to the number of non-agglutinated particles. Standard errors are calculated on five determinations within one day.

tests. ${ }^{9}$ Since $5 \mathrm{mM}$ of $\mathrm{CaCl}_{2}$ appeared optimum, assays were performed at this concentration.

\section{ANALYTICALRECOVERY}

$\mathrm{S}-100$ was assayed in $22 \mathrm{CSF}$ samples mixed with an equal volume of either GBS containing $5 \mathrm{mM} \mathrm{CaCl}_{2}$ and $10 \mathrm{~g} / \mathrm{l} \mathrm{bSA}$ or the same medium containing $50 \mu \mathrm{g} / \mathrm{l}$ of S-100. Analytical recovery was $95 \%$ with a coefficient of variation (CV) of $13 \%$.

\section{PRECISION}

The intra-assay precision was studied in three CSF samples containing $7 \cdot 7,11$ and $19 \mu \mathrm{g} / \mathrm{l}$ of $\mathrm{S}-100$, the assays being repeated 10 times on the same day. The CV were respectively $12 \cdot 7,4 \cdot 7$ and $4.4 \%$. The inter-assay precision was studied on samples at three concentrations of $\mathrm{S}-100,4 \cdot 5,9 \cdot 9$ and $24 \mu \mathrm{g} / \mathrm{l}$, the assays being repeated once each day for 8 days. The CV were respectively $16 \cdot 9,7$ and $6 \cdot 7 \%$.

\section{S-100 LEVEL IN THE CSF. AN INDEX OF CNS \\ DAMAGE}

Seventy-one samples out of $397(18 \%)$ contained detectable amounts of S-100 $(>2.5 \mu \mathrm{g} / \mathrm{l})$. The CSF samples from 29 non-neurological patients and from patients with sciatica $(\mathrm{N}=20)$, cervical arthrosis myelopathy $(N=17)$, lumbar stenosis $(N=9)$, degenerative disorders of the CNS $(N=12)$ and seizures $(\mathrm{N}=3)$ were apparently devoid of S-100.

High levels of S-100 and a high proportion of positive samples were found in four types of neurological diseases: compression of the spinal cord by tumour, ischaemic disorders, subarachnoid bleeding

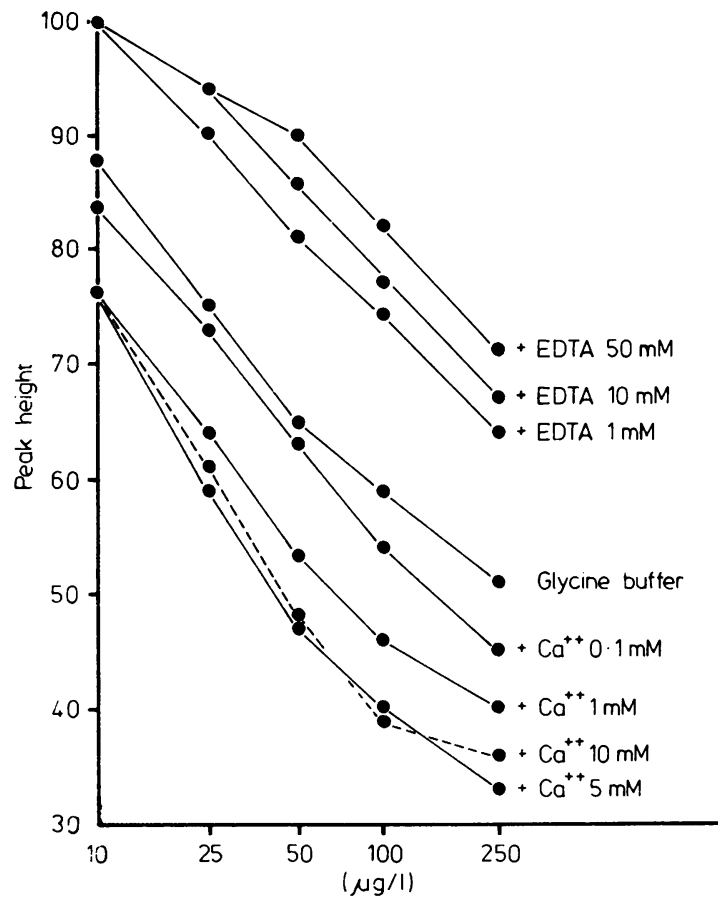

Fig 3 Effect of $\mathrm{Ca}^{++}$on the immunoassay of $\mathrm{S}-100$. In this experiment, $25 \mu$ lof various concentrations of $S-100$ diluted in GBS containing either EDTA or $\mathrm{CaCl}_{2}$ were vortex-mixed with $25 \mu$ lof the $F\left(a b^{\prime}\right)_{2}$ coated particles for 30 min at room temperature. The GBS ionic strength was kept constant by addition of sodium chloride. After mixing and appropriate dilution, the agglutination was measured as usual.

and haematoma, and viral or suspected viral infections (fig 4). All these disorders have in common acute damage of the CNS.

Samples with high concentration of S-100 were retested at three or four dilutions. All of the results were distributed in parallel to the calibration curve. Therefore one may assume that the immunoreactive material was actually S-100 and that fragments or aggregates of S-100 presumably did not interfere in the assay.

The patients of the stroke group were not representative of this type of disease because lumbar puncture is usually reserved for those with difficult diagnosis such as thrombosis of basilar and spinal arteries, which irrigate a relatively small region of the brain. In this case, less $\mathrm{S}-100$ should be released than in case of large hemispheric infarction. One has also to take into account that the CSF is often collected a few days after the stroke with the possibility, that 


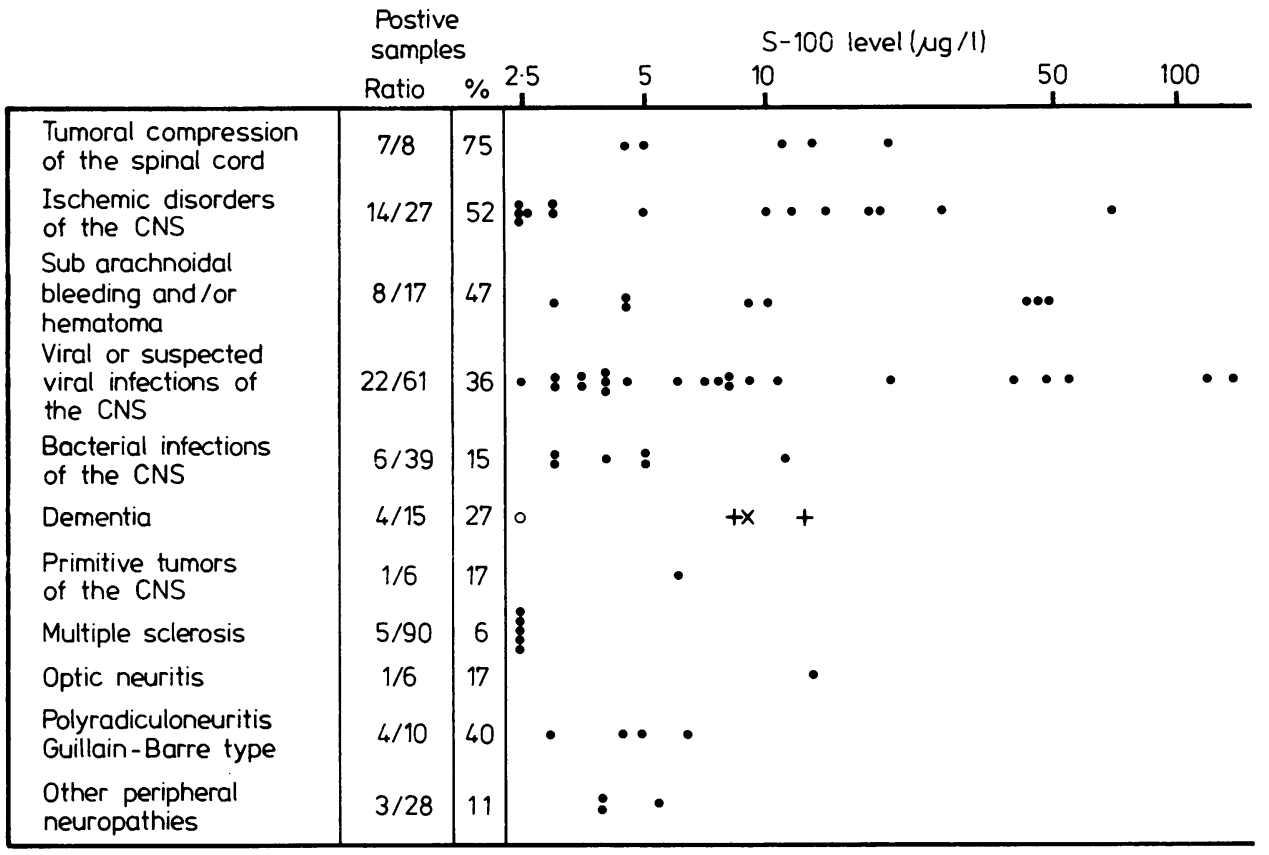

Fig 4 Determination of S-100 in the CSF of patients with various neurological disorders. The detection limit was $2.5 \mu \mathrm{g} / \mathrm{l}$ (+: Creutzfeldt-Jakob disease; $\times$ : multi-infarct dementia; O: pre-senile dementia).

S-100 released by the necrotic tissue has been eliminated.

Interestingly, in viral or suspected viral infections of the CNS, S-100 was found not only in patients with herpetic encephalitis and transverse myelitis, both of which extensively injure the CNS, but also in some patients with benign lymphocytic meningitis ( 5 cases out of 17). This suggests that the infectious process affected not only the meninges but also the nervous tissue. It should be noted that significant amounts of S-100 were found in the CSF of four patients out of 10 with Guillain-Barré polyradiculoneuritis, whereas only three patients out of 28 with other peripheral neuropathies were positive. High levels of S-100 in

Table CSF levels of S-100 and the patients' outcome

\begin{tabular}{|c|c|c|c|c|c|}
\hline Patients & Diagnoses & Samples & $\begin{array}{l}S-100 \text { levels } \\
(\mu \mathrm{g} / \mathrm{ll})\end{array}$ & $\begin{array}{l}\text { Interval between } \\
\text { onset of the disease } \\
\text { and sampling (days) }\end{array}$ & Outcome \\
\hline $\mathrm{RD}$ & Herpetic encephalitis & $\begin{array}{l}\text { 1st } \\
\text { 2nd } \\
\text { 3rd } \\
4 \text { th }\end{array}$ & $\begin{array}{c}48 \\
<2.5 \\
6 \\
8\end{array}$ & $\begin{array}{r}7 \\
13 \\
25 \\
32\end{array}$ & died \\
\hline GV & Herpetic encephalitis & $\begin{array}{l}\text { 1st } \\
\text { 2nd } \\
\text { 3rd } \\
4 \text { th }\end{array}$ & $\begin{array}{r}10.5 \\
8.8 \\
3 \\
<2.5\end{array}$ & $\begin{array}{r}3 \\
7 \\
9 \\
22\end{array}$ & partial recovery \\
\hline $\mathrm{RM}$ & Herpetic encephalitis & $\begin{array}{l}\text { 1st } \\
2 \text { nd } \\
3 \text { rd }\end{array}$ & $\begin{array}{r}<2.5 \\
3.5 \\
2.5\end{array}$ & $\begin{array}{r}3 \\
3 \\
4 \\
12\end{array}$ & complete recovery \\
\hline GM & Subacute transverse myelitis & $\begin{array}{l}1 \mathrm{st} \\
2 \mathrm{nd}\end{array}$ & $\begin{array}{l}20 \\
54\end{array}$ & $\begin{array}{l}28 \\
42\end{array}$ & no recovery \\
\hline ED & Subacute transverse myelitis & $\begin{array}{l}1 \mathrm{st} \\
2 \mathrm{nd}\end{array}$ & $\begin{array}{l}120 \\
140\end{array}$ & $\begin{array}{l}26 \\
42\end{array}$ & no recovery \\
\hline RC & Acute transverse myelitis & $\begin{array}{l}\text { lst } \\
\text { 2nd }\end{array}$ & $\begin{array}{r}40 \\
<2.5\end{array}$ & $\begin{array}{r}9 \\
23\end{array}$ & complete recovery \\
\hline JB & Stroke & $\begin{array}{l}\text { 1st } \\
\text { 2nd }\end{array}$ & $\begin{array}{l}70 \\
18\end{array}$ & $\begin{array}{r}2 \\
4\end{array}$ & partial recovery \\
\hline
\end{tabular}


two subsequent samples collected at one week interval from a patient with rapidly progressive Creutzfeld-Jakob disease emphasised the potential importance of the S-100 level as an index of CNS injury.

In most cases of multiple sclerosis we have failed to detect $\mathrm{S}-100$. Out of 90 samples five were only slightly positive. These results contrasted with those reported by Michetti et $\mathrm{al}^{3536}$ who found by complement fixation S-100 concentrations above $6 \mu \mathrm{g} / \mathrm{l}$ in the CSF of $70 \%$ of their patients with acute relapse of multiple sclerosis. This finding is rather surprising as recent immunohistochemical studies failed to detect S-100 in oligodendrocytes ${ }^{1113}$ which are selectively destroyed with the myelin sheath by multiple sclerosis. Whereas our 90 patients had low levels of S-100 one patient out of six with optic neuritis had a high level of S-100. One may therefore wonder whether this particular case was related or not to multiple sclerosis.

\section{PROGNOSTIC VALUE OF S-100 LEVELS}

In three patients with herpetic encephalitis we observed that the prognosis of the disease was related to the level of S-100 in the first sample of CSF taken during the acute phase of the disease (table). In our study of transverse myelitis, also restricted to three patients, the poor prognosis was associated more with increased or persistent high levels of S-100 than to the absolute value in the first sample. It should be noted that in a patient who recovered from stroke the S-100 level dropped from $70 \mu \mathrm{g} / \mathrm{l}$ to $18 \mu \mathrm{g} / \mathrm{l}$ in only two days.

In conclusion, our results support the assumption that $\mathrm{S}-100$ in the CSF is a reliable index of CNS injury $^{3536}$ and our study of a few patients suggest that the S-100 level and its changes could have a prognostic value.

We wish to thank MA Crépin and MP Van Antwerpen for skilfull technical assistance, Ms V de Chestret and Mr M Delory for competent editorial work and Dr H Holy for reviewing this paper. This work was supported by a grant from the "Fonds de la Recherche Scientifique Médicale" (No 3.4529.79).

\section{References}

1 Dannies PS, Levine L. Demonstration of subunits in beef brain acidic protein S-100. Biochimica et Biophysica Research Communications 1969;37:587-92.

2 Moore BW. A soluble protein characteristic of the nervous system. Biochimica et Biophysica Research Communications 1965;19:739-44.

3 Calissano P, Moore BW, Friesen A. Effect of calcium ion on S-100, a protein of the nervous system. Biochemistry 1969;8:4318-26.

${ }^{4}$ Steward JA. Tissue specific brain S-100. A demonstration of multiple proteins. Biochim Biophys Acta 1972;263:178-92.

s Isobe T, Nakajima T, Okuyama T. Reinvestigation of extremely acidic proteins in bovine brain. Biochim Biophys Acta 1972;263:178-92.

- Isobe T, Okuyama T. The amino acid sequence of S-100 protein (PAPI-b protein) and its relation to the calcium-binding proteins. Eur J Biochem 1978;89: $379-88$.

7 Isobe T, Ishioka N, Okuyama T. Structural relation of two S-100 proteins in bovine brain; subunit composition of S-100 protein. Eur J Biochem 1981; 115:469-74.

` Mahadik SP, Korenovsky A, Rapport MM. Heterogeneity of S-100 proteins of brain: subunit compositions. J Neurochem 1979;33:751-62.

9 Mahadik SP, Graf L, Korénovsky A, Rapport MM. Immunochemical properties of S-100 proteins and their subunits. $J$ Neurochem 1979;33:763-71.

${ }^{10}$ Hyden H, McEwen BS. A glial protein specific for the nervous system. Proc Natl Acad Sci USA 1966;55: 354-8.

"Sviridov SM, Korochkin LI, Ivanov VN, Malteskaya EI, Bakhtini TK. Immunohistochemical studies of S-100 protein during postnatal ontogenesis of the brain of two strains of rats. J Neurochem 1972;19:713-8.

12 Matus A, Mughal S. Immunohistochemical localization of S-100 protein in brain. Nature 1975;258:746-8.

${ }^{13}$ Haglid KG, Hamberger A, Hansson HA, Hyden $H$, Persson L, Rönnback L. Cellular and subcellular distribution of the S-100 protein in rat and rabbit central nervous system. $J$ Neurosci Res $1976 ; 2: 175-91$.

it Ludwin SK, Kosek JC, Eng LF. The topographical distribution of $S-100$ protein and GFA proteins in the adult rat brain: an immunohistochemical study using horseradish peroxydase labelled antibodies. J Comp Neurol 1976;165:197-208.

15 Tabuchi K, Kirsch WM, Nakane PK. The fine structural localization of $S-100$ protein in rodent cerebellum. $J$ Neurol Sci 1976;28:65-76.

16 Moller M, Ingild A, Bock E. Immunohistochemical demonstration of S-100 protein and GFA protein in interstitial cells of the rat pineal gland. Brain Res 1978; 140: $1-13$

17 Ghandour MS, Langley OK, Labourdette G, Vincendon G, Gombos G. Specific and artefactual cellular localization of S-100 protein: an astrocyte marker in rat cerebellum Dev Neurosci 1981;4:66-78.

is Legrand $\mathrm{CH}$, Clos J, Legrand $\mathrm{J}$ et al. Localization of S-100 protein in the rat cerebellum: an immunoelectron microscope study. Neuropathol App Neurobiol 1981;7:299-306.

19 Cocchia D. Immunocytochemical localization of S-100 protein in the brain of adult rat. An ultrastructural study. Cell Tissue Res 1981;214:529-40.

20 Cocchia D, Michetti F. S-100 antigen in satellite cells of the adrenal medulla and the superior cervical ganglion of the rat. An immunochemical and immunocytochemical study. Cell Tissue Res 1981;215:103-12.

${ }^{21}$ Cocchia D, Miani N. Immunocytochemical localization of the brain-specific $S-100$ protein in the pituitary gland of adult rat. J Neurocytol 1980;9:771-82. 
${ }^{22}$ Nakajima T, Yamaguchi H, Takahashi K. S-100 protein in folliculostellate cells of the rat pituitary anterior lobe. Brain Res 1980;191:523-31.

${ }^{23}$ Cocchia D, Michetti F, Donato R. Immunochemical and immunocytochemical localization of S-100 antigen in normal human skin. Nature 1981;294:85-7.

${ }^{24}$ Gaynor R, Irie R, Morton D, Herschman HR. S-100 protein is present in cultured human malignant melanomas. Nature 1980;286:400-1.

25 Gaynor R, Herschman HR, Irie R, Jones P, Morton D, Cochran A. S-100 protein: a marker for human malignant melanomas? Lancet 1981;i:869-71.

26 Pfeiffer SE, Kornblith PL, Cares ML, Seals J, Levine L. S-100 protein in human acoustic neurinomas. Brain Res 1972;41:187-93.

27 Zuckerman JE, Herschman HR, Levine L. Appearance of a brain-specific antigen (the $\mathrm{S}-100$ protein) during human foetal development. J Neurochem 1970;17: 247-51.

2* Cambiaso CL, Goffinet A, Vaerman JP, Heremans JF. Glutaraldehyde-activated aminohexyl derivative of Sepharose 4B as a new versatile immunoabsorbent. Immunochemistry 1975;12:273-8.

29 Sindic CJM, Collet-Cassart D, Cambiaso CL, Masson PL, Laterre EC. The clinical relevance of ferritin concentration in the cerebrospinal fluid. $J$ Neurol Neurosurg Psychiatry 1981;44:329-33.

${ }^{30}$ Booher S, Sensenbrenner M. Growth and cultivation of dissociated neurons and glial cells from embryonic chick, rat and human brain in flask cultures. Neurobiology 1972;2:97-105.

${ }^{31}$ Cambiaso CL, Leek AE, Dé Steenwinkel F, Billen J, Masson PL. Particle counting immunoassay (PACIA). I.-A general method for the determination of antibodies, antigens and haptens. $J$ Immunol Methods 1977;18:33-44.

${ }^{32}$ Limet JN, Moussebois CH, Cambiaso CL, Vaerman JP, Masson PL. Particle counting immunoassay. IV.-The use of $F\left(a b^{\prime}\right)_{2}$ fragments and $N$-chloracetyl Iysine $\mathrm{N}$-carboxyanhydride for their coupling to polystyrene latex particles. J Immunol Methods 1979;28:25-32.

${ }^{33}$ Sindic CJM, Chalon MP, Cambiaso CL, Collet-Cassart D, Masson PL. Particle Counting ImmunoAssay (PACIA). VI.-The determination of rabbit IgG antibodies against myelin basic protein using IgM rheumatoid factor. Molecular Immunology 1981;18: 293-9.

${ }^{34}$ Miles LEM, Lee YL, Eng LF. Calcium ion dependence of the 2-site immunoradiometric assay of Moore's S100 protein. J Neurochem 1977;28:1201-5.

${ }^{35}$ Michetti F, Massaro A, Murazio M. The nervous system specific S-100 antigen in cerebrospinal fluid of multiple sclerosis patients. Neurosci Lett 1979;11:171-5.

${ }^{36}$ Michetti F, Massaro A, Russo G, Rigon G. The S-100 antigen in cerebrospinal fluid as a possible index of cell injury in the nervous system. J Neurol Sci 1980;44: 259-63. 